KULTURA

i

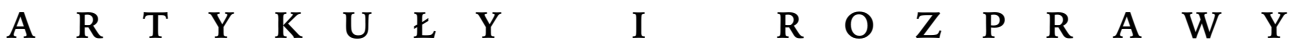

\section{SOCJOLOGIA CODZIENNOŚCI, CZYLI JAK PRZESTAĆ „BYĆ MODNĄ”?}

Rozważania te składają się z dwóch części. W części pierwszej spróbuję zastanowić się nad najważniejszymi powodami swoistej mody na socjologię codzienności. Gros tych powodów, według mnie, wiąże się ściśle z faktem przyjmowania do wiadomości - przez dużą grupę badaczy identyfikujących się z socjologią codzienności - określonych teoretycznych i metodologicznych metazałożeń odzwierciedlających ogólniejszy klimat teoretyczny cechujący całą współczesną socjologię. Tropienie owych, jak to określiłem, metazałożeń pozwala nie tylko lepiej uchwycić i zrozumieć specyfikę socjologii codzienności (choćby z tej przyczyny, że wskazuje na źródła jej inspiracji oraz na szersze, instytucjonalne uwarunkowania programujące jej oblicze), lecz również - co może w tym miejscu ważniejsze - pomaga zdać sobie sprawę z rozmaitych zagrożeń i pułapek, na jakie narażona jest ta (względnie ${ }^{1}$ ) nowa dyscyplina.

Adres do korespondencji: rafal.drozdowski@publicprofits.pl

${ }^{1}$ Nie chciałbym w tym miejscu wdawać się w (niewiele w sumie wnoszące) rozważania, czy i w jakim stopniu socjologia codzienności jest rzeczywiście nową perspektywą. Wśród prekursorów i zarazem bezpośrednich inspiratorów socjologii codzienności zwykle wymienia się dziś zgodnym chórem Georga Simmla i Ervinga Goffmana. Jednak równie łatwo byłoby wykazać teoretyczne pokrewieństwo między socjologią codzienności a na przykład chicagowską szkołą socjologii miasta lub niektórymi kontynuacjami interakcjonizmu symbolicznego (takimi choćby jak teorie emocji czy teoria stanów oczekiwań). Jeszcze łatwiej byłoby udowodnić, że założenia socjologii codzienności niewiele różnią się od teoretycznego i zwłaszcza badawczego programu etnometodologii bądź od programu brytyjskiej szkoły studiów kulturowych.

Tak czy inaczej nawet jeśli w stwierdzeniu, że zainteresowanie socjologów sferą codzienności jest tak stare jak sama socjologia, a przynajmniej, że nie jest ono aż tak bardzo nowe, jak chcieliby tego dzisiejsi promotorzy socjologii codzienności, kryje się sporo racji, to z pewnością trzeba ją przyznać także tym badaczom, którzy zwracają uwagę na fakt, iż dopiero stosunkowo niedawno socjologia zaczęła konsekwentnie „przymierzać się” do postrzegania praktyk codziennych jako najważniejszego spoiwa społeczeństwa (por. Certeau 2008). Stosunkowo też niedawno 
Paradoksalnie więc życzliwe nastawienie do socjologii codzienności wymaga dziś wzmożonego wobec niej krytycyzmu. Jej trwałe zadomowienie się na mapie socjologicznych orientacji i strategii badawczych stanie się możliwe jedynie wówczas, gdy będzie ona odpowiednio mocno i konsekwentnie dyscyplinowana przez krytykę domagającą się od niej coraz większego uporządkowania teoretycznego i metodologicznego.

W drugiej części z kolei będę chciał zwrócić uwagę na najbardziej prawdopodobne, moim zdaniem, negatywne konsekwencje, jakie przynieść może socjologii codzienności przeoczenie przez nią dylematów wynikających — pośrednio bądź bezpośrednio - ze wszystkich zewnętrznych wobec niej okoliczności towarzyszących jej formowaniu się i z przyjmowanych przez nią, nierzadko chyba dość bezwiednie, ogólniejszych założeń dotyczących obecnej sytuacji (teoretycznej, metodologicznej, instytucjonalnej) w socjologii tradycyjnej.

\section{DLACZEGO SOCJOLOGIA CODZIENNOŚCI STAJE SIĘ NA NASZYCH OCZACH POPULARNA I MODNA?}

Chciałbym tu wskazać na dziewięć — najważniejszych w moim przekonaniu - przyczyn owej (niewątpliwie) wzrastającej popularności socjologii codzienności, która chwilami rzeczywiście zaczyna wykazywać cechy nowej socjologicznej mody.

Po pierwsze, można więc chyba zaryzykować stwierdzenie, że wśród socjologów narasta przekonanie (słuszne czy niesłuszne - to całkiem inna sprawa), iż makrostrukturalny wymiar porządku społecznego jest coraz bardziej ukryty, coraz bardziej niewidzialny, że coraz trudniej rozszyfrować rządzące nim mechanizmy oraz tkwiące $u$ jego podstaw potoczne reguły i normatywne zasady.

W rezultacie kiełkuje w nas — jako socjologach — obawa, że wkrótce utracimy poznawczą kontrolę nad tradycyjnymi i niejako klasycznymi obszarami naszych zainteresowań badawczych (takimi choćby jak cała rozległa problematyka władzy czy jak kwestia makrostrukturalnych uwarunkowań wszelkich zmian społecznych), że staną się one po prostu niebadalne. Zwrot w stronę socjologii codzienności może w tej sytuacji uchodzić za rodzaj wygodnej i bezpiecznej (aczkolwiek trochę wymuszonej) alternatywy. Raz - dlatego że społeczna widzialność sfery codzienności nie budzi kontrowersji, przynajmniej na razie, takich jak społeczna widzialność procesów i mechanizmów sytuujących się na poziomie makrostruktur systemowych. Dwa — ponieważ

sfera codzienności doczekała się uznania za pełnowartościowy przedmiot badań socjologicznych. Inaczej mówiąc, badania dotyczące codzienności i funkcjonowania jednostek w tejże codzienności przestano traktować jako dopełnienie projektów badawczych nakierowanych na chwytanie prawidłowości i mechanizmów rządzących „wyższymi” poziomami porządku społecznego, a zaczęto $\mathrm{w}$ nich widzieć $\mathrm{w}$ pełni samoistny temat dla socjologii. 
zjawiska wpisujące się w ramy rzeczywistości życia codziennego sprawiają wrażenie znacznie łatwiejszych do badania.

Po drugie, socjologia codzienności wydaje się znakomitą, bardzo dobrze dopasowaną do oczekiwań socjologów obietnicą metodologiczną. „Standardowa skrzynka metodologiczna” socjologii jest wprawdzie zapełniona po brzegi, ale jednocześnie budzi ona w samych socjologach (i w ich klientach, zamawiających u nich badania) coraz większe wątpliwości i coraz większe znużenie. W tej sytuacji socjologia codzienności prezentuje się jako niepowtarzalna szansa na przerzucenie metodologicznego pomostu między socjologią a etnologią, antropologią kulturową, geografią społeczną, ekonomią, psychologią, a nawet intensywnie rozwijającymi się na naszych oczach badaniami, które podporządkowane są stricte marketingowym celom.

Można więc powiedzieć, że socjologia codzienności w pewnym sensie wykorzystuje kryzys zaufania do metod i technik badawczych socjologii głównego nurtu. Robi to przy tym dość sprytnie i przekonująco: nie postuluje bowiem żadnej rewolucji metodologicznej ani też nie zachęca do tego, aby zarzucić wszystkie stare i obłaskawione przez socjologów strategie badawcze, lecz przyobiecuje narzędziowe „dozbrojenie” socjologii dzięki programowi „metodologicznych pożyczek".

Po trzecie, mainstreamowa socjologia, odkrywszy globalizację (co prawda, nie sama, bo wespół z ekonomią, naukami politycznymi i studiami kulturowymi) i nauczywszy się coraz lepiej rozpoznawać oraz opisywać rozmaite tendencje i procesy składające się na to zjawisko, znalazła się w ślepym zaułku. $\mathrm{Z}$ jednej strony bowiem może $\mathrm{w}$ dalszym ciągu zajmować się - na coraz to nowe i inne sposoby - udowadnianiem globalizacji. Ale $z$ drugiej strony: jeśli rację ma na przykład Zygmunt Bauman (2000, s. 71-73) - przekonujący, że globalizacja jest $\mathrm{w}$ swojej istocie spontanicznym i chaotycznym procesem, za którym nie stoją żadni autorzy i żadni sprawcy, lub jeśli dać wiarę Edmundowi Wnuk-Lipińskiemu (2004, s. 159-167) albo Jadwidze Staniszkis (2003, s. 16-17), według których globalizacja niesie ze sobą głęboki, strukturalny kryzys idei państwa narodowego, gdyż kompromituje jego sprawczość - to należałoby powiedzieć, że wszystkie te coraz lepiej uświadamiane i coraz lepiej rozpoznane przez socjologię tendencje i procesy określane przez nią jako globalizacja stawiają pod znakiem zapytania zasadność dalszych nadziei socjologii na konstruowanie przez nią (bądź choćby tylko inspirowanie) jakichkolwiek programów socjotechnicznej interwencji nakierowanych na wspieranie i stymulowanie pozytywnych przekształceń.

Znów zatem - perspektywa socjologii codzienności może tu uchodzić za dobre, polubowne rozwiązanie. Gwarantuje ona bowiem socjologom komfort polegający na wycofaniu się ku tym obszarom świata społecznego, których na 
razie nie dotyczą dylematy i rozterki związane z ustalaniem granic indywidualnej podmiotowości. Socjologia codzienności, zwracając się w stronę zainteresowania (niemal wyłącznie) tymi praktykami społecznymi, które usytuowane są „na samym dole” porządku społecznego, bierze więc po prostu $\mathrm{w}$ nawias, jak się wydaje, wszelkie pytania o przyczynowość i o sprawstwo na wyższych piętrach porządku społecznego. W rezultacie jednak może jawić się jako nieco kapitulancka i konserwatywna perspektywa socjologiczna. Może kojarzyć się z głębokim, strukturalnym regresem socjologii rozumianym jako jej „miniaturyzacja", jako jej przeorientowanie się na naukę, która nie stara się już interesować wielkimi problemami, dąży jedynie do tego, aby „rozpływać się” w socjoi psychokonkretach.

Po czwarte, socjologia codzienności doskonale wpisuje się $\mathrm{w}$ pewnego rodzaju schemat socjologicznej wiary, zgodnie z którym kołem zamachowym najważniejszych zmian społecznych jest oparta na refleksyjności autonomia oraz podmiotowość rozmaitych zbiorowych (i zwłaszcza indywidualnych) aktorów społecznych. Taka wizja socjologii zwraca ją w stronę koncepcji teoretycznych zorientowanych na opisywanie i wyjaśnianie epizodów społecznego wytwarzania rzeczywistości. Czyni z niej łowcę i kolekcjonera empirycznych dowodów potwierdzających możliwość realizacji określonego typu prywatnych, indywidualnych aspiracji podmiotowościowych. Ale taka wizja socjologii jest także równoznaczna z przyjęciem do wiadomości dość chyba jednostronnego modelu, w którym aktora społecznego przedstawia się jako $z$ natury rzeczy refleksyjną jednostkę (i jako jednostkę zorientowaną na autonomię, na szukanie szczelin w porządku systemowym). Oczywiście - za taką perspektywą przemawia ogromna część dorobku teoretycznego socjologii (poczynając od Webera, poprzez Blumera i Schütza, a na Giddensie kończąc). Jednak wspomniana perspektywa wydać się może również zbyt liryczna. Pomija ona na przykład złożony i coraz żywiej dyskutowany w socjologii problem nawykow ości (w rozumieniu, jakie nadaje temu pojęciu choćby Jean-Claude Kaufmann - por. 2004, s. 151-152). Pomija ona także fakt, iż tożsamość indywidualna jednostek nie jest - na co zwraca uwagę na przykład Jürgen Straub (2006, s. 1122-1123) - wytworem „mocnego podmiotu”, lecz rezultatem ścierania się autonomii i heteronomii.

Po piąte, wydaje się, że socjologia codzienności dowartościowuje aktorów społecznych również $\mathrm{w}$ inny sposób. Przyjmując, że są oni interesujący dla socjologii nie tylko jako uczestnicy jakichś ważnych i przełomowych wydarzeń zmieniających architekturę porządku społecznego, lecz także jako uczestnicy i „wytwórcy” z pozoru nieefektownej i banalnej społecznej normalności, na swój sposób ich uwzniośla i czyni z nich swoich permanentnych, nie zaś tylko odświętnych bohaterów. Nie mam nic przeciwko takiemu myśleniu. Jednak pod warunkiem, że nie 
opiera się ono na chłodnej kalkulacji nakazującej zainteresować się „zwykłymi jednostkami” wpisanymi w ramy „zwykłej codzienności” tylko dlatego, że zapewni to socjologii - przynajmniej na jakiś czas - wystarczająco szeroki "front empirycznych robót". I pod warunkiem, że wspomniany zwrot socjologii w stronę zainteresowania społecznymi normalsami nie stępia jej wyczulenia na wszelkie przejawy społeczno-kulturowej inności i nie odwraca jej uwagi od zjawisk, które zachodzą w szczelinach legitymizowanego porządku.

Po szóste, wydaje się, że od dłuższego czasu sygnalizowany przez socjologię kryzys intersubiektywności w ostatnich latach się nasila ${ }^{2}$. W rezultacie socjologia dzisiejsza wraca do wielu wątków problemowych jeszcze do niedawna uznawanych za przebrzmiałe (na przykład do kwestii procesów więziotwórczych — por. Marody, Giza-Poleszczuk 2004), po to by - z jednej strony lepiej zrozumieć przyczyny i mechanizmy owej rozpadającej się intersubiektywności, z drugiej zaś - znaleźć odpowiedź na pytanie, jak tej tendencji przeciwdziałać.

W okolicznościach tych zwrócenie się w stronę codzienności i uczynienie przedmiotem badawczego zainteresowania socjologii działań oraz procesów, które z uwagi na ich „banalnośc”" traktowała ona dotychczas raczej po macoszemu, uznane być może za wcale dobre i obiecujące posunięcie. Nie tylko dlatego, że na najniższym piętrze porządku zbiorowego rzeczywiście dużo się dzieje. I nie tylko dlatego, że socjologia schodząc na to najniższe piętro ma szansę $\mathrm{w}$ szybkim tempie odrobić szereg własnych tematycznych przeoczeń (na przykład wytykany jej przez feminizm brak zainteresowania pracą domową kobiet lub wytykany jej przez etnologię brak zainteresowania materialnościa). Również dlatego, a w zasadzie przede wszystkim dlatego, że socjologia codzienności zwracając się $\mathrm{w}$ stronę praktyk codziennych, będących (o czym wiemy w socjologii od dawna) najważniejszym polem ucierania się, wytwarzania i potwierdzania (ale zarazem rozbijania) poczucia intersubiektywności, może prezentować się jako naprawdę ważny fragment współczesnej socjologicznej refleksji. Ważny, bo dotykający prawdziwie strategicznej kwestii szans i warunków utrzymania niezbędnej spójności i integracji społeczeństwa.

Samo w sobie zainteresowanie codziennością mogłoby — w innych okolicznościach - uchodzić za rodzaj badawczego ekscentryzmu. Ponieważ jednak socjologia codzienności deklaruje, że jest (że może być, że powinna być) tym

2 Kryzys ten potwierdzają na przykład tak różne poparte badaniami koncepcje, jak z jednej strony mieszcząca się w szerokim nurcie socjologii podmiotowości koncepcja Putnama (2008), który wieści kres zaangażowania obywatelskiego, a z drugiej strony na przykład wiele koncepcji formułowanych na gruncie medioznawstwa i szkoły badań kulturowych (zob. np. Morley 2000; Halawa 2006), które wskazują na to, że postępujący w błyskawicznym tempie proces tematycznej i gatunkowej specjalizacji na rynku medialnym skutkuje coraz większą segmentacją publiczności medialnej. 
nurtem socjologii, który — wbrew pozorom — nie zajmuje się „błahostkami”, nie koncentruje swojej uwagi na rozmaitych malowniczych, ale pozbawionych bardziej dalekosiężnego znaczenia zjawiskach, lecz próbuje — przynajmniej odpowiedzieć na pytanie, jakie stare i nowe „kleje” są w stanie w dalszym ciągu trzymać jednostki razem, prezentuje się ona tym samym niemalże jako ostatnia nadzieja nauk społecznych.

Po siódme, wydaje się, że socjologia codzienności d o sko nale odpowiada na podskórne tęsknoty socjologii za indukcjonizmem. Niezależnie od tego, że dawno już nauczyliśmy się traktować indukcjonizm jako — może i pożądany — lecz w praktyce niewykonalny postulat teoretyczny, owa tęsknota za budowaną od dołu teorią socjologiczną co jakiś czas powraca choćby pod postacią mieszanych uczuć, z jakimi witane są przez dużą część środowiska socjologów kolejne próby skonstruowania wielkiej teorii socjologicznej (wystarczy wspomnieć w tym miejscu pełną ambiwalencji recepcję teorii Niklasa Luhmanna) lub pod postacią wybuchów mody na typowe badania socjograficzne, mające jakoby uratować socjologię przed całkowitym rozpłynięciem się $\mathrm{w}$ abstrakcyjnych spekulacjach (lub w rozważaniach snutych w konwencji luźnego eseju).

W okolicznościach tych socjologia codzienności może sprawiać wrażenie strategii badawczej, która „sprowadza socjologię na ziemię”, lecz która jednocześnie nie przestaje nosić wszelkich znamion ogólnej ramy teoretycznej. Można więc powiedzieć, że socjologia codzienności ma prawo prezentować się jako wręcz optymalny program dla całej socjologii (por. Sztompka 2007, s. 33; Sztompka 2008, s. 48-50), gdyż (1) uwalnia ją od podejrzeń, że straciła ochotę, by (w dalszym ciągu) intensywnie badać życie społeczne we wszelkich jego przejawach i aspektach, a zarazem (2) proponując się jako pewna ogólniejsza rama teoretyczna, nie przekreśla nadziei na to, że wszystkie owe „zwiady badawcze” nakierowane na badanie „najniższych”, często na pierwszy rzut oka zupełnie trywialnych poziomów rzeczywistości społecznej będzie się dało zsumować w jakiś model o niepodważalnej doniosłości teoretycznej.

Po ósme, socjologia codzienności może być - bez większych kontrowersji - uznana za jedną z tych perspektyw teoretyczno-badawczych, które nobilitują s z c z e g ól, czyniąc zeń pierwszoplanowy przedmiot socjologicznej analizy. Obietnica drobiazgowego oglądania i analizowania rzeczywistości społecznej, obietnica wniknięcia w jej najdrobniejsze niuanse i w umykające uwadze większości badaczy mikroprzejawy wzorów oraz reguł porządku zbiorowego pozwala widzieć w socjologii codzienności nie tylko szansę na niezliczone nowe projekty i przedsięwzięcia badawcze, lecz także fantastycznie skuteczny sposób na ratowanie socjologii przed wielokrotnie wytykaną jej pokusą pochopnych ustaleń i przedwczesnych uogólnień. Co więcej, można by w tym miejscu powiedzieć, że owo zwrócenie się socjologii 
codzienności w stronę szczegółów może być traktowane jako jej odpowiedź na (wcale często) stawiany całej socjologii zarzut, iż tak naprawdę przyczynia się ona do utrwalania moralnej nieuwagi, objawiającej się „myśleniem w kategoriach statystycznych", które usuwa z pola widzenia wszystko, co nie układa się w tendencje.

I po dziewiąte, wydaje się, że socjologia codzienności jest dobrą odpowiedzią na pewne znużenie ponowoczesnością w naukach s połecznych. Przywraca ona bowiem - choć pewnie mimowolnie - założenie, że istota porządku społecznego wyraża się (jednak) w typowościach, nie zaś w różnicach. Zajmując się raczej procesami społecznego wytwarzania i społecznego potwierdzania normalności niż procesami, w wyniku których tworzą się i zostają lepiej lub gorzej zalegitymizowane określone nisze porządku systemowego i określone „enklawy ograniczonego znaczenia”, socjologia codzienności dokonuje, jak się wydaje, swoistego zwrotu w stronę „starej, przedponowoczesnej socjologii" dążącej - właśnie - bardziej do ustalania tego, co aktorów społecznych łączy, niż tego, co ich dzieli i co ich odróżnia od siebie. W ten sposób socjologia codzienności, prezentując się jako - w znacznym stopniu — „nowy program”, jest również w stanie zadowolić socjologicznych konserwatystów.

Ów podskórny (przynajmniej „opcjonalny”) konserwatyzm socjologii codzienności $z$ jednej strony czyni $z$ niej znakomite narzędzie mogące służyć dobrze pojętemu dy scypli now ani u zapatrzonych w „perspektywę postmodernistyczną" i na swój sposób od niej uzależnionych narracji socjologicznych. $Z$ drugiej strony zaś równie łatwo wyobrazić sobie, że zostanie on — prędzej czy później - wykorzystany do kompromitowania tych nurtów socjologii, które nie czują się zobowiązane do upominania się o interesy (jakkolwiek rozumianej) większości.

\section{SOCJOLOGIA CODZIENNOŚCI — (NIEPEŁNA) LISTA DYLEMATÓW, PUŁAPEK I „SPRAW DO ZAŁATWIENIA”}

Socjologia codzienności wydaje się dzisiaj w szczególny sposób narażona na zarzut, iż nie potrafi przekonująco odpowiedzieć na pytanie, po co właściwie badać codzienność? Można, co prawda, udzielić na tak postawione pytanie odpowiedzi najprostszej z możliwych: należy badać codzienność po to, aby po prostu więcej o niej wiedzieć i aby „zinwentaryzować” jej wszelkie przejawy, trochę na podobieństwo fotografa, który dokumentuje rzeczywistość taką, jaką ją zastaje i tak jak ją widzi, ażeby potwierdzić jej istnienie i prolongować pamięć o niej na wypadek, gdyby uległa implozji, „zapadła się w sobie” bądź została w taki czy inny sposób - symbolicznie lub fizycznie - zlikwidowana.

W rzeczywistości jednak owo pytanie, po co badać codzienność, jest tak naprawdę pytaniem o to, czy i co socjologia codzienności mówi na temat wła- 
snych, być może charakterystycznych wyłącznie dla siebie, modeli eksplanacyjnych. Inaczej mówiąc, jest to pytanie o to, co da się wyjaśnić przez badanie codzienności?

Wydaje się, że pierwsza, akceptowana przez socjologię codzienności strategia eksplanacyjna przedstawia się następująco: wszelkie praktyki społeczne wpisujące się $\mathrm{w}$ ramy rzeczywistości życia codziennego mogą być traktowane jako pośrednie bądź bezpośrednie wskaźniki określonych ogólniejszych tendencji i mechanizmów składających się na poziom makrostrukturalny porządku społecznego. W takim ujęciu poziom mikroładu zbiorowego potrzebny jest socjologii jako rodzaj linku odsyłającego „do góry”.

Drugą, równie chyba szeroko aprobowaną dziś przez socjologię codzienności strategią eksplanacyjną jest ta, zgodnie z którą wpisane $\mathrm{w}$ codzienność mikropraktyki społeczne mogą być również traktowane jako zapowiedź zmian strukturalnych zachodzących na makropoziomie porządku społecznego, jako mniej albo bardziej wyrazisty zwiastun rozmaitych nowych tendencji społeczno-kulturowych. Tak rozumiana socjologia codzienności staje się zatem sposobem i techniką wyśledzania pierwszych symptomów zmian społecznych.

I na koniec jeszcze jedna, trzecia, możliwość: wszystkie mikropraktyki dochodzące do głosu na poziomie najbardziej choćby banalnej codzienności mogą być także traktowane jako w wysokim stopniu autonomiczne, samoorganizujące się i samozwrotne „wycinki” rzeczywistości społecznej. Przy takim postawieniu sprawy badana codzienność nie odsyła do niczego poza nią samą. Niczego nie symbolizuje ani nie metaforyzuje. Niczego też nie zapowiada ani niczego nie programuje.

Nietrudno zauważyć, że strategia pierwsza w zasadzie unieważnia trzecią. Tym samym niesie ze sobą niebezpieczeństwo przeoczenia (1) tych wszystkich sytuacji, które można by określić mianem epizodów autoteliczności w życiu społecznym oraz (2) tych wszystkich ujawniających się w obrębie codzienności praktyk, które mają charakter samozwrotny.

$Z$ kolei druga strategia eksplanacyjna wydaje się ryzykowna przede wszystkim $z$ tego powodu, że grozi zawężeniem programu badawczego socjologii codzienności wyłącznie do postulatu wyławiania „epizodów niecodzienności”, o których chce się myśleć jako o pierwszych jaskółkach nadchodzących zmian i przeobrażeń o szerszym zasięgu społecznym. Doszukiwanie się w (dzisiejszych) wyjątkach zapowiedzi (jutrzejszych) wzorów o szerokim zasięgu obowiązywania jest oczywiście bardzo nęcące. Jednak postępowanie takie, paradoksalnie, w ostatecznym rozrachunku deprecjonuje codzienność, skłania do tego, by się nią zajmować jedynie fragmentarycznie i wycinkowo - by interesować się tylko tymi jej mikrocząstkami, które mogą zwiastować jakieś zasadnicze zmiany.

I jeszcze kilka zdań na temat trzeciej wspomnianej strategii eksplanacyjnej. Postulat ujmowania codzienności jako (zasadniczo) autonomicznej i samozw- 
rotnej sfery niesie ze sobą ryzyko popadnięcia w „socjologiczny autyzm”, przez który można rozumieć przekonanie, że coraz więcej z tego, co uwidzialnia się na poziomie codzienności ma czysto prywatny rodowód oraz odzwierciedla wyłącznie indywidualne aspiracje do autonomii (nie zaś jakiekolwiek ogólniejsze uwarunkowania historyczne, ekonomiczne, polityczne, kulturowe itd.). Postulat ten — zwłaszcza w jego radykalnej postaci — na dłuższą metę musi oznaczać postępujące „odsocjologicznienie socjologii”).

Trudno będzie uchylić się $\mathrm{w}$ tym miejscu od odpowiedzi na pytanie, która $z$ trzech wyodrębnionych wyżej strategii eksplanacyjnych najlepiej pasuje do socjologii codzienności? Wydaje się, że pierwsza z nich może najbardziej „podobać się" socjologom identyfikującym się z szeroko rozumianą tradycją postdurkheimowską, druga - zwolennikom rozmaitych teorii podmiotowości, trzecia zaś - socjologom utożsamiającym się z socjologią ponowoczesną. Koniec końców rzecz nie w tym jednak, komu podoba się która strategia (i dlaczego?), lecz w tym, że trwałe uprawomocnienie się socjologii codzienności w środowisku socjologów (i tym bardziej zyskanie przez socjologię codzienności zaufania wśród wszystkich ewentualnych odbiorców jej empirycznych ustaleń) wymaga od niej uporządkowania myślenia na temat (1) jejwłasnych funkcji oraz (2) zakresu jej stosowalności. Oczywiście - wszystkie trzy strategie eksplanacyjne, o których tu piszę, mogą być równie dobre (lub równie złe), zależnie od kontekstu ich użycia. Pierwszoplanowym zadaniem dla socjologii codzienności staje się więc jak najszybsze i jak najbardziej klarowne określenie przez nią (i uzgodnienie z jej sceptykami), co to oznacza - w praktyce określenie „właściwe konteksty jej użycia”.

Drugie istotne zagrożenie, na jakie narażona jest socjologia codzienności, wiąże się w moim przekonaniu $z$ faktem, iż wydaje się ona skrojona raczej „na czas społecznej i politycznej pogody" niż na bardziej burzliwe okresy w dziejach społeczeństw. Nie chcę przez to powiedzieć, że badając codzienność nie można badać zmian społecznych (jest chyba dokładnie na odwrót: łatwiej uchwycić zmiany społeczne i ich kierunek schodząc na poziom mikropraktyk niż obserwując zachowanie się mezo- i makrostruktur). Idzie mi raczej o to, że socjologia codzienności może być łatwo oskarżona, iż jest perspektywą teoretyczną, która bagatelizuje najważniejsze wyzwania i problemy współczesności, rozpływając się $\mathrm{W}$ anegdotycznych badaniach i orientując się na tematy mogące sprawiać wrażenie drugorzędnych bądź zastępczych.

Niezależnie od tego, czy socjologia codzienności zdążyła już sobie zasłużyć na powyższy zarzut (moim zdaniem, jest on na razie nietrafny i sformułowany stanowczo na wyrost), faktem jest, że powinna jak najprędzej zacząć uprawomocniać się przez konsekwentne pokazywanie, w jaki sposób swoistość jej spojrzenia na świat społeczny, swoistość jej strategii badawczych, swoistość jej aparatu pojęciowego itd. mają szansę przyczynić się do lepszego rozpoznania i zrozumienia przyczyn oraz mechanizmów „dziania się” rzeczywistości 
społecznej w jej najbardziej newralgicznych przejawach i aspektach (takich jak wytwarzanie i proliferacja społecznych nierówności, procesy marginalizacji i wykluczania, rosnący prywatyzm itp.).

Owo wpisywanie się socjologii codzienności w szeroki program socjologii, który nakierowany jest na gaszenie złych skutków modernizacji oraz na przeciwdziałanie wszelkiego typu negatywnym zjawiskom pozbawiającym całe segmenty społeczeństwa poczucia bezpieczeństwa $\mathrm{w}$ istniejącym porządku społecznym, musi być - w zasadzie - równoznaczne z jej upolitycznieniem. Niesie ono ze sobą bardzo wiele (nowych) dylematów i zagrożeń. Ale koniec końców wspomniane upolitycznienie wydaje się dla socjologii codzienności o wiele mniejszym ryzykiem niż jej a- lub antypolityczność.

Po trzecie, socjologia codzienności, chętnie prezentując się jako wybitnie „miękka” wersja współczesnej socjologii (nawiązująca raczej do tradycji socjologii humanistycznej i sięgająca raczej po jakościowe metody i techniki badawcze), naraża się tym samym na zarzut teoretycznej i metodologicznej jednostronności. Podobne zarzuty stawiane były w przeszłości na przykład interakcjonizmowi symbolicznemu lub etnometodologii. Problem jednak w tym, że sytuacja socjologii codzienności jest specyficzna, albowiem usytuowane na poziomie codzienności jednostkowe praktyki są szczególnie mocno powiązane z czynnikami i z uwarunkowaniami, którymi socjologia (ani ta miękka, ani ta twarda) w zasadzie się nie zajmuje (za to znajdują się one w polu zainteresowania na przykład psychologii ewolucyjnej, socjobiologii lub antropologii fizycznej). Innymi słowy, ów zarzut teoretycznej i metodologicznej jednostronności może być - w przypadku socjologii codzienności - szczególnie druzgocący, gdyż oznacza w tym przypadku oskarżenie, iż tak naprawdę znakomitej większości badanych przez nią zjawisk, procesów i mechanizmów najzwyczajniej nie da się wyjaśnić za pomocą tradycyjnych zmiennych socjologicznych i przy użyciu zadomowionych w socjologii procedur badawczych.

Dobrym wyjściem z tego impasu i z tej swoistej pułapki mógłby okazać się na przykład „trudny sojusz” socjologii codzienności z najbardziej „antykulturalistycznymi" orientacjami we współczesnych naukach społecznych (por. Wilson 2002, s. 275-317; van den Berghe 1991, s. 321-351). Sojusz taki, jakkolwiek na pierwszy rzut rzeczywiście trudny i „egzotyczny”, mógłby uwolnić socjologię codzienności od zarzutu, że jest ona ucieleśnieniem takiego programu nauk społecznych, który Edward Wilson nie tak dawno określił mianem programu SSSM (Standard Social Science Model) i który poddał druzgocącej krytyce, gdyż — jego zdaniem - usilnie dąży on do wyjaśniania zjawisk społeczno-kulturowych wyłącznie za pomocą zmiennych $z$ tego samego, społeczno-kulturowego poziomu (por. Wilson 2002, s. 285-31733). Poza tym mógłby on wymusić na so-

\footnotetext{
${ }^{3}$ Może zaskakiwać, że podobną myśl wyraził Jean Baudrillard (2001, s. 56-57).
} 
cjologii codzienności większe zdyscyplinowanie metodologiczne. Mógłby także przyczynić się do tego, że socjologię codzienności zaczęto by postrzegać jako ten wariant współczesnej socjologii, który jest najbardziej otwarty na rozmaite projekty interdyscyplinarne i który przyjmuje do wiadomości, iż wyłącznie socjologiczny punkt widzenia co do takich czy innych problemów społecznych nie wystarcza, by je w pełni zrozumieć i zadowalająco wyjaśnić.

Po czwarte, socjologia codzienności, wykazując się daleko posuniętą ostrożnością w kwestii wszelkiego typu programów i projektów socjotechnicznych, naraża się jednak tym samym na zarzut, że jest socjologią zainteresowaną jedynie kontemplowaniem rzeczywistości społecznej i nie aspiruje do tego, by ją tak czy inaczej zmieniać.

$\mathrm{Z}$ jednej strony miałbym ochotę powiedzieć, że to $\mathrm{w}$ sumie dobrze, iż socjologia (przynajmniej ta zainteresowana codziennością) podchodzi z dużą ostrożnością i z dystansem do rozmaitych form socjologicznego interwencjonizmu (gdyż nazbyt pochopne lub niekiedy za bardzo idealistyczne programy interweniowania $\mathrm{w}$ tkankę życia społecznego dotychczas przynosiły socjologii więcej szkody niż pożytku i raczej podkopywały jej naukowy autorytet niż go umacniały). Jednak $z$ drugiej strony jeśli socjologia codzienności chce skutecznie bronić się przed zarzutem, iż nie jest niczym więcej niż wgapianiem się w takie czy inne epizody potwierdzania bądź przetwarzania porządku społecznego, usytuowane na jego najniższym, najbardziej podstawowym poziomie, to powinna dążyć — bardziej stanowczo i bardziej konsekwentnie niż do tej pory - do prezentowania się jako subdyscyplina, która ma (może mieć) konkretne praktyczne zastosowania. Socjologia codzienności jest w stanie dostarczać interesujących i wartościowych danych na przykład specjalistom od ergonomii, planistom miejskim, urbanistom, antropologom wielkich organizacji biznesowych, specjalistom od relacji międzykulturowych itd. Musi tylko nauczyć się szybciej i lepiej rozpoznawać ich potrzeby badawcze.

Po piąte, socjologia codzienności przez wielu może być dzisiaj odbierana jako nowa wersja etnocentryzmu. Ci, którzy przyglądają się jej poczynaniom bez zbytniej życzliwości, mogą bowiem traktować ją jako zbiór opowieści przedstawicieli społeczno-kulturowego mainstreamu, snutych na temat życia mieszkańców rozmaitych społeczno-kulturowych peryferii, jako (nowy) program wędrówki w głąb egzotyki własnego społeczeństwa.

Innymi słowy, socjologia codzienności może uchodzić za (jeszcze jeden) rodzaj ukrytego i zawoalowanego konserwatyzmu, który pod pozorem realizowania określonych zadań poznawczych dokonuje egzotyzacji wzorów i postaw nie mieszczących się w kulturze głównego nurtu. Socjologowie, którzy zajmują się badaniem codzienności, mogą być więc postrzegani jako „podróżnicy po własnym społeczeństwie", którzy jednakże — paradoksalnie - wykazując 
zainteresowanie określonymi praktykami, poniekąd je stygmatyzują i „folkloryzują".

Jeśli socjologia codzienności chce się uchronić przed podobnymi zarzutami, to powinna wystrzegać się wszelkiego normatywizmu, a w rzeczy samej powinna być możliwie jak najbardziej „insiderska” i możliwie jak najmniej „ciekawostkowo-anegdotyczna".

Można trzymać kciuki za socjologię codzienności na różne sposoby. Ja starałem się tutaj być takim jej kibicem, który życząc jej jak najszybszego teoretycznego i metodologicznego okrzepnięcia, stara się zwrócić uwagę na jej niedostatki.

Rzecz nie tyle w bezpardonowym krytykowaniu socjologii codzienności (co do tej pory jest dość łatwe), lecz w tym, by ją prowokować do większego samokrytycyzmu, pomagającego odbić się od własnych ograniczeń. Im szybciej socjologia codzienności zacznie uściślać własne reguły i własne tryby funkcjonowania (ale też uświadamiać sobie własne nieprzekraczalne bariery), tym szybciej stanie się nie tylko pełnoprawnym, lecz także, najprawdopodobniej, dominującym nurtem w całej współczesnej socjologii i jej największą nadzieją.

\section{BIBLIOGRAFIA}

Bauman Zygmunt, 2000, Globalizacja. I co z tego dla ludzi wynika, tłum. Ewa Klekot, Państwowy Instytut Wydawniczy, Warszawa.

Baudrillard Jean, 2001, Przed końcem (rozmowy), tłum. Renata Lis, Sic!, Warszawa.

Certeau Michel de, 2008, Wynaleźć codzienność. Sztuki działania, tłum. Katarzyna Thiel-Jańczuk, Wydawnictwo Uniwersytetu Jagiellońskiego, Kraków.

Halawa Mateusz, 2006, Życie codzienne z telewizorem, Wydawnictwa Akademickie i Profesjonalne, Warszawa.

Kaufmann Jean-Claude, 2004, Ego. Socjologia jednostki. Inna wizja cztowieka i konstrukcji podmiotu, tłum. Krzysztof Wakar, Oficyna Naukowa, Warszawa.

Marody Mirosława, Giza-Poleszczuk Anna, 2004, Przemiany więzi spotecznych. Zarys teorii zmiany spotecznej, Scholar, Warszawa.

Morley David, 2000, Home Territories: Media, Mobility and Identity, Routledge, New York.

Putnam Robert D., 2008, Samotna gra w kregle. Upadek i odrodzenie wspólnot lokalnych w Stanach Zjednoczonych, tłum. Przemysław Sadura i Sebastian Szymański, Wydawnictwa Akademickie i Profesjonalne, Warszawa.

Staniszkis Jadwiga, 2003, Wtadza globalizacji, Scholar, Warszawa.

Straub Jürgen, 2006, Tożsamość osobista i zbiorowa, tłum. Mirosława Marody, w: Aleksandra Jasińska-Kania, Lech Nijakowski, Jerzy Szacki, Marek Ziółkowski (red.), Wspótczesne teorie socjologiczne, Scholar, Warszawa.

Sztompka Piotr, 2007, Zaufanie. Fundament społeczeństwa, Znak, Kraków.

Sztompka Piotr, 2008, Życie codzienne - temat najnowszej socjologii, w: Piotr Sztompka, Małgorzata Bogunia-Borowska (red.), Socjologia codzienności, Znak, Kraków. 
Wilson Edward O., 2002, Konsiliencja. Jedność wiedzy, tłum. Jarosław Mikos, Zysk i S-ka, Poznań.

Wnuk-Lipiński Edmund, 2004, Świat międzyepoki. Globalizacja, demokracja, państwo narodowe, Znak-Instytut Studiów Politycznych PAN, Kraków.

Van den Berghe Pierre L., 1991, Łaczenie paradygmatów: biologia i nauki społeczne, w: Barbara Szacka, Jakub Szacki (red.), Człowiek, zwierzę społeczne, Czytelnik, Warszawa.

\section{THE SOCIOLOGY OF EVERYDAY LIFE, OR HOW TO STOP BEING FASHIONABLE}

\section{Summary}

In the first part of the article are presented the most important reasons for the recent increase in interest in the sociology of everyday life. Some of them are related to the situation in which sociology as a whole finds itself today (for example the interest, typical for the sociology of everyday life, in the processes occurring on the micro-level may be treated as the result of the fears of sociologists about the investigation of increasingly hidden macro-structural processes). The fashion for the sociology of everyday life seems also to be a result of the calculation of sociologists; the sociology of everyday life turns out to be a beneficial theoretical research position, allowing a compromise between many traditionally opposing theoretical positions (such as actor-structure, the creation and reproduction of rules for collective order etc.). The attraction of the sociology of everyday life is due to the fact that it gives hope for the modernisation of the "tool kit" of sociology and is an attempted remedy for boredom in the "Post-Modern Sociology", at least in the sense that it again proposes sociologists to focus attention more on similarities than differences.

In the second part of the article, the author concentrates on a selection of the problems with which the sociology of everyday life is faced. The most important of them can be summarised by the question: why do we study everyday life? The answer to this question is an attempt to define three different explanatory models according to which everyday practice is seen as (1) a reflection of phenomena and processes which occur at a macrostructural level, or (2) a preview of macrostructural changes or, finally, (3) an autonomic sphere of social life which cannot be treated as an "indicator".

\section{Key words/słowa kluczowe}

sociology of everyday life / socjologia codzienności; social micropractices / mikropraktyki społeczne; explanatory models / modele eksplanacyjne 